http://dx.doi.org/10.12775/szhf.2016.056

\title{
Pętko Panny Maryjej albo sposób oddawania się Błogosławionej Pannie Marii za sługę i niewolnika
}

\section{CZĘŚĆ PIERWSZA}

W której się pokazuje, iż słusznie za Niewolnika Najświętszej Panny oddajemy

\section{Rozdział I}

Iż Najświętsza Panna Maryja Panią naszą dziedziczną i przyrodzoną jest; a my też sługami i niewolnikami jej dziedzicznymi i przyrodzonymi

Jest Błogosławiona Panna naszą przyrodzoną i dziedziczną Panią, a my sługami i Niewolnikami jej, także dziedzicznymi i przyrodzonymi. Bo jeżeli Syna Bożego, człowieka i Boga prawego, który się w żywocie jej Panieńskim, że Krwawej, sprawą Ducha Świętego się począł i z niej się urodził. Panią była; a on także (jako święty Łukasz mówi Rozd. 2 v.51) ${ }^{1}$ poddanym jej był, we

${ }^{1}$ Zapis poprawiony za E. Reczek, Wstęp, [w:] Niewolnictwo Mariańskie. Dwie Publikacje Polskich Jezuitów z roku 1632, opracował Eugeniusz Reczek, Rzym 1964. Oryginalnie: „Rozd. 20”. 
wszystkim wolą jej i rozkazanie pełniąc; toć tez i wszystkie rzeczy ta Maria najgodniejsza, poddaństwo $\mathrm{z}$ nim wespół odebrała a zatem stała się Panią wszystkich rzeczy które jego były; a one stały się poddanymi i niewolnikami Panny tak chwalebnej. Albowiem jeżeli synowie, według prawa przyrodzonego, sługami są rodziców swoich; a rodzice $\mathrm{z}$ tegoż przyrodzonego prawa panami też są synów, tych, których zrodzili toć daleko więcej, pannami są rodzice, tych do rzeczy do synów swoich należących, które na nie spadają przyrodzonym prawem.

A przetoż ponieważ ta najgodniejsza Pani nasza Maryja przyrodzoną i prawdziwą jest Matką Bożą bo Syn jej, Chrystus Pan, jest Bogiem prawdziwym: toć tedy przyrodzoną i dziedziczną Panią będzie, tak syna swego Boga prawdziwego jako też i rzeczy podległych jego panowaniu; a zatem nas wszystkich. Bo jeżeli Bóg samego siebie przyrodzonego Pana wszystkich rzeczy stworzonych pod panowanie i rząd przeczystej Panny Matki swojej podał; jako poddać nie miał rzeczy inszych wszystkich które nieskończonemi sposobem podlejsze i mniejsze, niżeli on, były. Inaczej wielka byłaby ujma tak zacnemu macierzyństwu stała. Zaczym i to idzie iż naród ludzki który jest przedniejszą częścią rzeczy stworzonych rzeczy poddanym stał tej Pannie i Matce: do czego słusznie ją Panią swoją; a samego siebie sługą jej najpodlejszym i wiecznym niewolnikiem zowie ${ }^{1}$.

Słuchaj co i tym, Kościelni Doktorowie mówią; Święty Jan Damascen (Orat 2. de Assumpt. SS Dei Genitricis²) takimi słowy, to jej państwo nad stworzeniem wszystkim opisuje. Potrzeba tego było, aby jej wszystkie rzeczy które własne byly Syna jej odziedziczyła; $i$ aby jej wszystkie stworzone jako Matce Bożej służebnicy pokłon oddawały. Bo aczkolwiek ten tryb jest pospolity $w$ prawie przyrodzonym, iż po rodzicach swoich, Synowie na majętność następują, i dziedzicami się prawdziwymi stają teraz jednak iż słowo u człowieka jednego (Euripidis in Medea) zażyję; opak się świętych rzek wody obróciły. Albowiem, Syn Matce, wszystkie rzeczy stworzone pod moc i pod władzę poddał. Tenże (Orat. 2 sup. Cit and intionum ${ }^{3}$ ) przydaje i mówi: Życzę sobie tego, aby mi miłościwa była ta, która chwalić i wielbić poczynam; Która wszystkie rzeczy stworzone przychodzi godnościa, i nad nim wszystkimi panuje; jako Matce Boga wszechmocnego. Który stwórca jest i sprawca wszystkiego; a wszystkie stworzone sa pod władza jego.

\footnotetext{
${ }^{2}$ Joannis Damasceni, Opera magna... ex parte nuc de integro conversa per D. Jacobum Bilium... Parisiis 1603, folio 355 verso.

${ }^{3}$ Tamże.
} 
Toż państwo Błogosławionej Pannie, przyznawa Święty Antanazus Arcybiskup Aleksandryjski (Serm. de. SS nostra Deipara sub finem ${ }^{4}$ ) gdy mówi: A ponieważ Królem jest ten, który się z Panny rodzi i tenże zaraz Panem jest i Bogiem; toć tedy dlatego i Matka jego, która zrodziła Królowa jest i Pania prawa; Dobrze ja tedy i stusznie barzo [bardzo - P. Rz.] Bogurodzica nazywamy. Nuż i doktor Anielski Tomasz Święty, toż o niej potwierdza, (Opusc. 8 in Exposit. Salut. Angelicae ${ }^{5}$ ) i mówi: Słusznie barzo Anioł Błogosławionej Pannie cześć wyrządza; bo Matka Pańska; i dlatego Pania jest, dlatego też to imię MARJA, barzo jej przystoi; Którym imieniem w Syryjskim języku Pania nazywają. Jeszcze dość jaśniej Bonawentura Święty (in Speculo Beatae Virginis MARIAE, lect. seu cap. 3 post medium ${ }^{6}$ ) to państwo Błogosławionej Pannie, nad wszystkim stworzeniem przyznawaj i mówi: MARYJA wykłada się Panią. Które imię barzo dobrze przystoi, tak wielkiej i zacnej Cesarzowej, Którą zaprawdę Pania jest niebieskich, ziemskich i piekielnych rzeczy. Paniq prawi jest Aniołów, Pania ludzi, Pania czartów przeklętych; Paniq na niebie, Pania na ziemi, Pania w piekle samym. Na też niemal słowa zgadza się z nim Arnold Carnotensis, Opat Bonaevallis (in Serm. Del laudibus MARIAE ${ }^{7}$ ), gdy tak mówi: MARIA z Syryjskiego języka, Panią się nazywa Chrystusowa zowie, to jednak służebnictwo jej większe jest niż najwyższe Królestwo. Albowiem postanowiona jest nade wszystko stworzenie, i kiedykolwiek się JEZUSOWI kłania, tenże Matce jego niziuchna czesść oddawać musi.

Lecz ze wszystkich, najdoskonalszą i najwyraźniejszą o tym Państwie Błogosławionej Panny, naukę, podaje Bernard Seneński (Tomo I. Operum Ser. 61 art. 1 cap $\left.6^{8}\right)$. Którego słowa aczkolwiek przydłużnym, niewadzi położyć [przytoczyć - P. Rz.] Tak wiele; mówi, stworzenie służy Błogosławionej Pannie, jako wiele służy Trójcy przenajświętszej. Wszystkie abowiem stworzone rzeczy, na którymkolwiek stopniu stworzenia posadzonę sa; bądź Duchowne jak Aniołowie; bądź rozumne jako ludzie; bądź z ciała złożone jako sa nieba, żywioły i wszystkie rzeczy, które sa na niebie i na ziemi; bądź potępieni,

\footnotetext{
${ }^{4}$ Sancti Athanasii Magni, Alexandrini archiepiscopi Scriptoris Gravissimum Opera quae extant ominia.... Coloniae Agrippinae 1617, s. 262.

${ }^{5}$ D. Thomae Aguintin, Opera omnia, t. 17 cz. 1, Romae 1570, folio 75-76.

${ }^{6}$ Sancti Bonaventurae, Operum tomus sextus continens priam et secundum partem opusculorum... tomus sextus et septimus complectens et quartam partem Opusculorum... t. 6, Moguntiae 1609, s. 433.

${ }^{7}$ Marguerin de La Bigne, Magna Bibliotheca Veterum Patrum, et antiquorum Scriptorum ecclesiasticorum Coloniae Agripinae 1619, s. 436-438.

${ }^{8}$ Berninandus Senensis, Opera quae extant omnia ..., Venetiis 1591, t. 1, s. 514.
} 
bądź błogosławieni: i owszem wszystko co jest $w$ mocy i panowaniu Boskiemu podległe, to się też Błogosławionej Pannie zna i wie być poddany. Abowiem ten, który Synem Bożym byt i Synem Przebłogosławionej Panny; chcac (że tak rzeknę) Ojcowskiemu Państwu niejako porównać państwo macierzyńskie: sam który Bogiem był, matce służył na ziemi dlaczego też, o niej i o Józefie Łukasz święty Ewangelista (R 2. V51.) napisał; że im był poddanym. Do tego; Każdy snadno [łatwo - P. Rz.] przyzna iż to jest prawdziwa nuka. Boskiemu rozkazaniu, podległe i posłuszne sa wszystkie rzeczy: i Panna chwalebna. Powtóre i ta druga jest prawdziwa nauka. Rozkazaniu i państwu Pańskiemu podległe sa wszystkie rzeczy, i Bóg sam. I niżej przydaje tenże (w Rozdziale 7) ${ }^{10}$. A przetoż, dziedzicznym prawem, należy Błogosławionej Pannie przełożeństwo i Królestwo wszystkiego świata. Bo aczkolwiek ta Błogosławiona Panna, najzacniejsza była persona, $z$ tych które były abo i będa na ziemi; i doskonałości; że choćby nie była, jako teraz jest Matka Boża; przecięby była musiała być Paniq wszystkiego świata i wedle prawa i ustaw, którymi się ludzie na tym świecie rzadzą: prawem dziedzicznym, wszystkiego świata. Królestwa by była i państw dostała, albowiem Syn jej w pierwszym zarazem momencie poczęcia swojego, zastużył sobie i otrzymat państw nad wszystkim stworzeniem, jako mu to Prorok w Pslamie 23 v 1 przyznawa. Pańska jest ziemia i napełnienie jej; okrag ziemi $i$ wszyscy którzy mieszkaja na nim. A przetoż tym prawem, że Syna Bożego poczęła; należało to Pannie o to się wszystko starać, i tym rzadzić, co na ten czas Synowi jej dano, aż do slusznych lat tego Syna swego; jako tej która go najpilniej żywiła, karmiła chowała, jako prawa każa. Przydaje i dalej. I owszem gdy Syn jej jedyny umierał, na Krzyżu; gdy żadnego nie miała na ziemi któryby po nim, wedle prawa, na państwo nastąił; Matka na wszystkie dobra jako pozwalaja prawa nastapiła; i przez to się Pania wszystkich rzeczy stała. A żeby prawo to następnej jej na dobra synowskie kiedykolwiek od niej odjąć miano, tego nigdzie zgoła nie czytamy; i owszem za dziwnym zrzadzeniem Boskim, i za łaska tej Panny widzimy, że się najjaśniejszej to państwo wydaje: gdy ja wszystkich rzeczy stworzonych zowiemy Pania i Królowa. Zamyka, tak długi dyskurs swój, ten Święty kochanek, i prawdziwy Niewolnik MARYJI Panny. Z tego wszystkiego dosyć się jaśnie pokazuje, że Matka najgodniejsza Chrystusa JEZUSA, MARYJA; dziedzicznym prawem, nad wszystkimi rzeczami, które sa mniejsze niżli Bóg; Królewskie, panowanie i najzacniejsze państwo otrzymała.

\footnotetext{
${ }^{9}$ Poprawione przez E. Reczka. Oryginalnie: „R 2. v5”.

${ }^{10}$ Berninandus Senensis, Opera quaes..., s. 514.
} 
A przetoż ktokolwiek się oddał za wiecznego Przenajświętszej Pannie, Niewolnika; nie daj się nigdy krewkości uwodzić; abyś tej Pani swojej kiedy zapomniawszy; udać się miał do twardego jarzma, tyrana jakiego piekielnego. Staraj się o tym zawsze z pilnością największą, aby się jako sługa dobry, w żadnej rzeczy najmniejszej Pani twojej nie sprzeciwiał; i takich rzeczy nie czynił, które oczom jej Świętym nie podobają; wszystek wolę twoją, miej na najmniejsze jej skinienie gotową; czyniąc to wszystko ochotnym [ochoczym - P. Rz.] sercem cokolwiek rozkaże; Mówże tak do niej często, i sercem i ust. Rozkaż mi Pani moja, co chcesz, i coś się podoba; wszystko to ochotnie odprawię, pójdę u na kraj [kraniec - P. Rz.] świata, gdy będzie rozkazanie twoje; żadne mię trudności nie odstraszą, niebezpieczeństwa, żądnie nie odwrócą, żadnej by największe prace nie zasmucą. A widząc to, żeć [że Tobie - P. Rz.] wszystek świat i wszystkiego stworzeniu hołduje; przyznawam i ja ciebie Panią moję o wielka Matko Pana mego; przed twymi się nogami i najpodlejszego Niewolnika twego, niziuchno podkładam. Podepczże głowę moję, która byłą do tych czas uporna, Pani moja Wielmożna, której się z wiecznego Niewolnika oddał; opanuj mię i serce moje, które przed tobą tak długo stroniło. Zarzuć łańcuch na szyję moję, i pęta na ręce i nogi, a zamknij mię do więźnia twego, wespół, z tymi, którycheś ty sobie niewolnikami wiecznymi uczyniła i do Niewoli twojej zaciągnęła. Oto teraz trzymam to pęto, znak niewoli mojej przed obliczem twoim, z tym się protestując, że od tych czasów swobodę moję odawszy, już niechcę być moim, ale wiecznie twoim. Przyjmijże mię, o Pani moja, za Niewolnika twego: Mów to słowa wesołe: Jesteś sługą moim : a ja też sercem całym i radości nieograniczonej pełnym będę mówił. Jesteś Panią moją. Której dziedzicznym i przyrodzonym prawem stałem się wiecznym niewolnikiem. Zarzekam się od tego czasu, pani moja najłaskawsza, wszelkiej wolności; zarzekam własnej woli mojej; którą tym świętymi pętami związaną i skrępowaną, pod nogi święte Majestaty twojego podkładam. Przyjmijże zbiega swawolnego, poskrom zwiąskami [więzami P. Rz.] twoimi, odziedziczył na wieki sługę, więźnia i niegodnego Niewolnika twego. Oto się ja, wolnym językiem, przed światem wszystkim protestuję i wyznaczam wam jawnie: że jest wiecznym Niewolnikiem twoim: i owszem z Niewolników wszytki podłych najpodlejszym. 


\section{Rozdział II \\ Najświętsza Panna Maryja uczyniła nas niewolnikami swymi na wcielenie Syna Bożego, zezwoliwszy}

Nuż kiedy jeszcze uważamy, iż ta przenajświętsza Pani i Matka Boża MARYJA, nie tylko jest przyrodzoną i dziedziczną Panią naszą ale też niewolnikami swymi kupiwszy nas sobie, uczyniła. Albowiem gdybyśmy byli po przestępstwie pierwszych rodziców naszych w Raju, synami gniewu i grzechu, sługami diabelskimi, niewolnikami śmierci doczesnej i wiecznej; od której żadną miarę, wykupieni byśmy być nie mogli od stworzeni żadnego szczerego za Dekretem Boskim: ona sama zezwolenie swoim wcielenie Syna Bożego, przez słowo ono wesołe (Stan mi się) od tej niewoli czartowskiej nas wyzwoliła.

Temu się przypatrując, i to jej zbawienie nasze przymawiając Bernard Święty mówi. (Hom: 4 super Missus est) ${ }^{11}$ Styszałaś, prawi Błogosławiona Panno, ze poczniesz i porodzisz Syna: Styszałaś, ze się to stanie, nie sprawa ludzka, ale sprawa Ducha świętego. Oczekiwa Anioła odpowiedzi twojej, aby się wrócił do Boga który go posłał. Oczekiwamy i my Pani nasza, tego słowa zmiłowania twego, którzy cierpiemy jarzmo barzo ciężkie Dekretu, który na potępienie nasze jest wydany. Otoć [przecież - P. Rz.] ofiarują okup zbawienia naszego jeżeli zezwolisz, zarazem wybawieni będziemy, a którzyśmy byli, dla grzechu naszego umarli; tak krótką odpowiedziawszy twoja do żywota się znowu przywróćmy. Tego od ciebie żebrze, o najłaskawsza Panno płaczliwy Adam ze wszystkich utrapionymi pokoleniem swoim $z$ Raju dla swego przestępstwa wygnany. Tego żebrze wszystek świat, przypadwszy na kola swoje. I słusznie to bardzo ponieważ z ust twoich, wyniść na pociecha nędzników mizernych odkupienie więźniów, wyzwolenie potępionych zbawienie, co największa wszystkich Synów Adamowych; i owszem wszystkiego narodu twojego. Patrz, że i sam Król najwyższy i Pan wszystkiego stworzenia, czeka i pragnie odpowiedzi twojej, bo przez cię wszystkie świat zbawić postanowił. Co gdyż tak jest któż będzie śmiał mówić, że ja nie niewolnik i sługa MARYJI? I toć uważając Augustyn Święty (Serm. $2^{12}$. In Festo Annunciat. Dominincae) ${ }^{13}$ taka do tej Panny rzecz i przemowe czyni. O błogosławiona MARYIA, któż cię godnie będzie mógł

${ }^{11}$ Divi Bernardi Doctoris Mellitissimi, ac Primi Abbatis Clarcevallensis Conobii... Opera, Venetiis 1583, t. 1 f. $15 \mathrm{v}$.

12 Poprawione przez E. Reczka. Oryginalnie: „Serm. 1”.

${ }^{13}$ S. Aurelii Augustini, Opera tomis 10 comprehensa; per Theologos Lovanienses ex manuscriptis codicibus..., Parisis 1614, t. 10, s. 413. 
wychwalać, i dzięki oddać ostatecznie. Któraś osobliwym twoim zezwoleniem świat ginacy z niebezpieczeństwa wieczny zguby wyważyłaś? Jaka chwałę odda ułomności i nieudolności rodzaju Ludzkiego, która nieudolność nie inszym sposobem tylko przez cię, i przez zapłate twoja drogę do wyszycia [wyzwolenia się - P. Rz.] swego z niewoli, tak ciężkiej nalazła?

\section{Rozdział III}

\section{Błogosławionej panny Maryi niewolnikami jesteśmy, iż nas od śmierci wieczystej wybawiła, do zbawienia się naszego przyczyniwszy}

Lecz nie tylko tym zezwoleniem swoim wykupiła, i niejako zbawiła nasz Przenajchwalebniejsza Panna; ale też i inszym sposobem to jest, część długi którymś Bogu byliśmy winni, zaś za nas zapłaciwszy, co ona uczyniła częścią na ten czas, kiedy Synowi Bożemu, w żywot jej z ojczyzny niebieskiej zastępującemu, ciało ze krwi swej panieńskiej dał; a nad to i żywota i naturę ludzką częścią i na ten czas kiedy pod Krzyżem przy śmierci i męce tegoż jednego Syna swego stojąc; nie tylko krew Synowską, która też jej krwią niejako była, ale i samego Syna swego przedwiecznemu Bogu Ojcu zaś nas i za grzechy nasze, jako najwdzięczniejszą ofiarę i całopalenie, ochotnie ofiarowała. A jeżeli Bogu Ojcu, dlatego że Syna swego za nas wydał, i nie przepuścił mu; i Synowi, że się sam dobrowolnie na śmierć, i męki tak okrutne ofiarował, zbawienie nasze przyznawamy; czemu i tej matce, swym sposobem, zbawienia tego nie przyznamy; Która Syna swego miłego i jedynego, sercem mężnym dobrowolnie i ochotnie za nas ofiarowała, zbawienia tego nie przyznamy? Jeszcze dalej i stąd przyznać się jej to zbawienie musi, i owszem Odkupicielką nazywać ją możemy: że wespół z Synem swoim, dla zbawienia naszego dla zbawienia naszego cierpiącym, patrząc na niego tak bardzo bolesnego i bolała sama i wiele cierpiała. Świadczy o tym sama Przenajświętsza Panna, która do Brigitty Świętej (1. Reuelationum cap. 27) ${ }^{14}$ mówi. $Z$ jak wielu żył Krew jego (to jest Chrystusa Pana) przenajdroższa wyszła tak wiele włóczni serce moje żałosne przebyly. I przedaje nieżej [niżej - P. Rz.] w Rozdziale $35 .{ }^{15} \mathrm{~A}$ dlaczego to tak śmielę mówię, że boleść jej była boleścia moją; bo i serce jego było sercem moim. Abowiem jako Adam i Ewa przedali świat za jedno jabłko; tak ja z Synem moim odkupiliśmy świat jednym niejako sercem.

\footnotetext{
${ }^{14}$ Revelationes Sancte Brigittaae olim a card. Turrecremata recognitae, Romae 1628, s. 59.

${ }^{15}$ Poprawnione przez E. Reczka. Oryginalnie: „w rozdziale 27”. S. Revelationes Sancte Brigittaae, s. 75.
} 
Pięknie to wyraził Arnoldus Carnotensis (Abbas Bonaesvilis in serm. de Ladubimus MARIAE, Quid habtetur in 2 parte tomi 2 Bibliothae Patrum) ${ }^{16}$ gdy tak o tym mówi: Na ten czas kiedy Apostołowie pouciekali, Matka sama w oczach Synaczka swojego stanęła, przebijał miecz ostry boleści, dusze jej żałosną; zraniał się duch jej $i$ afekt krzyżowat; i owszem cokolwiek sprawowat $w$ ciele Chrystusowym gwoździe i włócznia bok jego przebijająca, toż i w sercu jej użalenie przyrodzone i afekt macierzyński sprawił. Stała pod Krzyżem nie poczynając sobie tego za wzgardę choć Matka Chrystusowa była; podobno dlatego, że tak rozumiała, iż przy śmierci Syna swego ona też śmiercia swoja przydać cokolwiek na wykupienie światła zgubionego mogła. Przydaje tenże Arnold na początku miejsca wzwyż podmienionego i mówi. Poruszała go (to jest JEZUSA Pana na Krzyżu wiszącego) macierzyński miłość; i jednakże na ten czasy była na ten czas była JEZUSOWA i MARYJI wola i jednejże ofiarę oddawali Bogu; MARYJA z krwi serca bolesnego, a JEZUSA we krwi ciała cierpiącego.

I też boleść jej Doktorowie Kościelni uważając Męczenniczką ją, i owszem więcej niżeli Męczenniczką; Królową męczenników zowią. Przyznawam jej to, i z pozwaleniem nie małym do niej mówi Bonawentura Święty (tom 2. Operum in stimulo Amoris p. 1. c. 3) ${ }^{17}$ O Pani moja gdzie na ten czas stała! Czyli tylko wedle Krzyża! I owszem na Krzyżu z Synem twoim ukrzyżowana była; ale $z$ ta różnica, że syn twój na ciele a ty na duszy, i na sercu twoim. A co większa, i rana jego które się były pociele jego wszystkie rozsadziły jedna ranę okrutna złączone w sercu twoim były. Tam Pani Moja przebite było włócznia serce twoje, tam ciężeniem ostrym ukoronowane, tam naśmiane naigrane i rozmaitej wzgardy napetnione, octem i żółcia gorzko napojone. O Pani Moja! Czemużeś szła za nas na grzesznych ofiarować? Czyli nie dosyć było na męce Synowskiej, ażby był i Matka ukrzyżowana! O serce miłości, jakożeś się obróciło, w jeden skład abo zebranie rozlicznych boleści! Patrzę, Pani moja na serce twoje, które nie sercem, ale miast niej, plwociny, bicz i rany znajduję. Boś się ty jedna $w$ to wszystko obróciła. O rzeczy podziwienia godna! Wszystka jesteś $w$ ranach Chrzystusowych. Wszystek Chrystus skrzyżowany jest we wnętrznościach twoich!

\footnotetext{
${ }^{16}$ Marguerin de La Bigne, Magna Bibliotheca Veterum Patrum, et antiquorum Scriptorum ecclesiasticorum, Coloniae Agrippinae 1618, t. 12, cz. 2, s. 436-438.

${ }^{17}$ Sancti Bonaventurae, Operum..., t. 7, Moquntiae 1609, s. 196.
} 
I owszem Hieronim Święty, więcej ją niżeli męczenniczką nazywa (tom 9. Qui inscirbitur Epistolarum Epist. 10 seu serm. De Assumpt B.V ${ }^{18}$ gdy mówi: Prawdziwie tedy Błogosławiona Matka Chrystusowa i Panna i Męczenniczka była albowiem prawdziwie cierpiała jako Symeon o niej prorokował. A twoje prawi, dusze przebił miecz boleści. (Łukasz Święty Rozdział 2. V.35 $5^{19}$ ) Skąd się pokazuje, iż więcej niżeli męczenniczka była. Albowiem inszy Świeci, aczkolwiek dla Chrystusa na ciele cierpieli: przecie jednak na duszy (gdyż nieśmiertelna jest) cierpieć nic nie mogli. Błogosławiona tedy Matka Boża, iż na tej części cierpiała, która jest niecierpiętliwa i dla tegoż (że tak rzekę) ponieważ duchownie, $i$ daleko ciężej cierpiała od miecza męki Chrystusowej; więcej też daleko niżeli męczenniczka była. Skąd jeszcze dalej swojego miłowała; dlatego też więcej daleko bolała tak dalece, że wszystka dusze jej przenikała i obejmowała ciężkość boleści, na wszytkę dusze jej przenikała i obejmowała ciężkość boleści na wyświadczenie miłości jej wielkiej. Co ponieważ na duszy cierpiał, więcej niżeli męczenniczka była. Abowiem boleść jej mocniejsza niżeli śmierć była, bo śmierć Chrzystusowa swoja uczyniła. Lecz najjaśniejsze jest świadectwo o Męczeństwie tym Przenajświętszej Panny które czytamy w Objawieni Brigitty Świętej Rozdział $52^{20}$ gdzie tak Chrystus Pan do przenajchwalebniejszej Matki swojej mówi: Daję to świadectwo, że ty przy męce mojej więcej niżeli męczenniczka była.

Z których słów, i z Doktorów Świętych: i owszem z rzeczy samej dosyć się jaśnie pokazuje, iż bez ujmy chwały Chrystusowej i Boga Ojca jego przedwiecznego: (bo i na nich chwała się Matki Bożej zlewa) ta Panna chwalebną nazywać się może i jest Panią naszą, a my słusznie jesteśmy i Niewolnicy, od niej summą tak drogą to jest krwią Syna jej JEZUSA, i boleściami jej tak ciężkimi, kupieni.

\section{Rozdział IV \\ Przenajświętszej Panny Maryjej słusznie, niewolnikami jesteśmy dlatego żeśmy od niej nieoskoczone prawie, dobrodziejstwa wzięli}

Jeszcze ktoby sobie dobrodziejstwa codzienne, które od tej Panny wziął i bierze ustawicznie wspominał; a nie tylko on, ale wszystkie naród ludzki;

\footnotetext{
${ }^{18}$ Tomus nonus Epistolarum D. Hieronymo falso adscriptarum... Ad Paulam et Eustochium... Sermo, qui Sophronii esse dicitur, Romae 1576, s. 66-79.

${ }^{19}$ Poprawione przez E. Reczka. Oryginalnie: „Rozdział 2 v. 25”.

${ }^{20}$ Revelationes Sancta Brigittae..., s. 144.
} 
ten zapewne nie tylko by się sługą i niewolnikiem jej ale bydlątkiem najpodlejszym i najposłuszniejszym nazywał i mówiłby sam do sobie często: Zostałem się bydlatkiem u ciebie a będę zawsze stoba (Psalm, 72, v.23)

Niechaj sobie każdy z ludzi na świecie żyjących przypomni, jako niesłychane, nieskończone rozumem ludzkim zalewie pojęte dobrodziejstwa każdego momentu na ciele i na duszy żyjące, jako i przy śmierci bierze, a uzna to łacno, że nie tylko sługą najpodlejszym, ale Niewolnikiem wiecznym jej nie tylko się nazywać ale owszem być i pragnie sobie tego, z serca uprzejmego będzie. A to jeszcze tym więcej gdy obaczy, iż żadnym inszym sposobem oddać nie może tej łaski. Dobrodziejce i Patronce tak szczodrobliwej jako tym jednym, za sługę się jej i Niewolnika wiecznego oddawszy.

Niechaj sobie każdy z ludzi na świecie żyjących przypomni, jako niesłychane, nieskończonej rozumem ludzkim zaledwie pojęte dobrodziejstwa każdego momentu na ciele i na duszy tak żyjąc, jako i przy śmierci bierze, a uzna łacno, że nie tylko sługą najpodlejszym ale Niewolnikiem wiecznym jej nie tylko nazywać, ale owszem być i pragnąć sobie tego, z serca uprzejmego będzie. A to jeszcze tym więcej, gdy obaczy, iż żadnym inszym sposobem oddać się mojej tej łaski. Dobrodziejce i Patronce tak szczodrobliwej, jako tym jednym, za sługę jej i Niewolnika wiecznego oddawszy.

Abowie jeżeli Tobiasz młodszy Rafałowi Aniołowi dla tego, że dobrodziejstw trochę, Ojcu jego i żonie uczynił, oddał się za sługę jako w Piśmie Świętym (Tob. 9. V. 2) czytamy: niewiedząc jakim by innym sposobem ta łaska jego mogła być jemu nagrodzona: co i mu uczynić też będziemy mieli, którześmy tak wiele dobrodziejstw od Przenajświętszej Panny MARYJEJ, Matki Bożej wzięli, na których wyliczanie, nie tylko czas wszystek żywota naszego, ale i wszystkich wieczności nie dosyć by była?

Nie masz żadnego dobrodziejstwa w nas którego by nie wzięli przez ręce MARYJEJ. Cóż albowiem wiem mamy, co jesteśmy co możemy czegobyśmy naprzód po Bogu i (jeżeli dźwięcznymi być chcemy). MARYEJ Pannie przypisać, przyznawać nie musieli? Jesteśmy na świecie; żyjemy zdrowie całe i siły nienaruszone mamy? Dobrodziejstwo stworzone Bogurodzicy Maryi sprawuje. Jesteśmy Chrześcijan i prawdziwie, nie między Pogaństwo zrodzeni i wychowani! Nuż w takim stanie, w wieku na tym miejscy, w czasie, w takiej familii, a takim personami, i okolicznościami? Dobrodziejstwo to MARYJEJ sprawuje. W łasce Bożej jesteśmy, żyjemy po grzechu popełniony; Bóg nas zaś grzechy nasze nie skarał jakośmy byli zasłużyli, ale użyczył jeszcze czasu do pokuty świętej? Wszystko to z łaski i dobrodziejstwa MARYJEJ pochodzi. 
Naostatek choćby człowiek dzień i noc złączywszy dobrodziejstwa te MARYJI Bogurodzicy wyliczał; pierwej nad sobą słońca i dzień zapadający, nawet i siły nadwątlone umarzał, niżeli te dobrodziejstwa tak wielkie Najświętszej Panny MARYJI wyliczy. Jednym słowem, każdy o sobie to powiedzieć można, co kochanek JEZUSOWY Bernard ŚWIĘTY mówi (Serm. 3. In Vigil. Nativ) ${ }^{21} Z a$ tego żaden sobie nie może rozumieć aby miał co dobrego $w$ sobie, czegoby nie wzią przez ręce MARYJI. I owszem to samo że żyjemy, ze tego momentu na świecie jesteśmy; łaską to i dobrodziejstwo Panny MARYJI sprawuje. Żeś niegodzien był mówi Bernard Święty Któremuby dobrodziejstwo dano; dano je MARYJI, abyś przez nie wziąt cokolwiek teraz masz. Abowiem niechciał Bóg abyśmy jakie dobodziestwo mieli, którebym pierwej nie przeszło przez ręce MARYJI.

I dlategoż, maż jeden doskonały (Idiota in Prologo Contemplat. de Virgine MARIA, quae habteur tomo 10 magnae Bibliothace Pastorum $)^{22}$ PODSKABINĄ ją najwyższą Pańską, i łask jego niebieskich Szafką nazywa; do której serca miłosiernego, jako do skarbcu jakiego złożył i wylał wszystkie skarby swoje jako Bernard Święty mówi (Deprecatione ad Gloariam Virginem MARIAM $)^{23}$ z którego skarbcu każdemu które chce grzesznikowi nabierać skarbów i czerpać Boskich łask obfitość wołano. Wszystkim ludziom, mówi Bernard S (Serm de B. Virgine MARIA) ${ }^{24}$ stała się użytą, we wszystkich rzeczach $w$ potrzebach szczodra, mądrym i nie mądrym $z$ najkwitniejszej miłości jakie długo zaznawał, jakoby im winna była wszystkie miłosierdzie swoje, co otworzyła, aby z jej petności brali wszyscy czegokolwiek potrzebować będa więzień odkupienie, chorych uzdrowienie, smutny pocieszenie, grzesznym odpuszczenie, sprawiedliwiym łaskę. Anioł pociechę. I naostatek Twoich przenajświętsza chwałę znamienitą.

Co głębiej uważając tenże Berdnard S. (in deprescat. Ad gloriam Virginem MARIAM) ${ }^{25}$ tak do niej sercem nabożnym, jako zwykła przemowę czyni. Ty się grzesznikiem by był najsprośniejszym, najgorszym mnie brzydzisz, nie odrzucasz go, gdy do ciebie westchnie; i gdyby twoja pomoc, serce żałosnym

${ }^{21}$ Divi Bernardi, Opera..., Venetiis 1583, t. 1, f. 20v.

${ }^{22}$ Marguerin de La Bigne, Magna Bibliotheca Veterum Patrum, t. 10, s. 27-30. Idiota (pseud.) = Roymundus Jordanus, prepozyt w Uzès i opat w Selles-sur-Cher w 1381, pisarz ascetyczny. Zob. U. Chevalier, Répertoire des sources historiques... bio-bibliographie, t. 1, kol 2240, 2650. [wyjaśnienie za E. Reczkiem].

${ }^{23}$ Divi Bernardi, Opera..., Venetiis 1583, t. 1, f. 120.

${ }^{24}$ Tamże, f. $101 \mathrm{v}$.

${ }^{25}$ Divi Bernardi, Opera Bernardi, Antverpia 1576, f. 101. 
i skruszony, żebrać, i o nię prosić ciebie będzie. Ty go z przepaści depresyjnej miłosierna twoja prawica wyciagniesz i wyprowadzasz. Ty nadzieje dodawszy i w niej zatrzymasz i nie odpuszczasz grzesznika, aż go na Trybunat Sędziego strasznego postawisz a bezpiecznie go tam zaprowadzisz temuż Sędziemu sprawiedliwemu mizernego i utrapionego nędznika z łaski twej niezmiernej przejednasz.

Co że ona snadnie [łatwo - P. Rz.] dosyć uczynić może; wywodzić i pokazanie pięknie, B. Piotr Damiani, w te słowa: (Serm 44, quid in Natiut B.V.) ${ }^{26}$ uczynit $w$ tobie wielkie rzeczy, ten który mocny jest $i$ dać jest moc, na ziemi i na niebie. A czegosz ty nie otrzymasz, któraś otrzymała aby Theophilus, którego zbawienie w ostatnim już bezpieczeństwie było; (Vide Surium Tomo I de Sanctis ad 4 diem Febr. ${ }^{27}$ od zguby się wiecznej do łaski może i żywota dobrego powici? Nieszczęsna dusze tego złośnika, który wszystkich rzeczy, w tobie sprawa boska poczynione potępił, i zaprzał [zaparł - P. Rz.] się ich, ręka swoja własna zapisawszy; z kałuży grzech i nędze wiecznej, tyś miłosierdziem twoim wydźwignęła. Nie masz u ciebie nic nie podobnego której podobno byt, desperatów obżałowanych i opłakiwanych, do nadziei błogosławienstwa, wiecznego przyprowadzić. Jako abowiem ona najwyższa moc, mocy twojej sprzeciwiać się może; która z ciała twego, początek ciała swego wzięła? Przystępujesz bowiem do złego onego, przez który się naród ludzki Bogu, Ojcu przejednał ołtarza; nie tylko prosząc ale rozkazując Pani już a nie stużebnica.

A co większa: obawiać się najmniejszej żadnemu nie trzeba, aby prośby i wzdychania jego nie słyszała; gdyż ona oprócz tej prośby i głosy naszego; potrzeby nasze wszystkie niedostatki, nędzę, utrapienia i owszem skrytość wszystkich serc naszego dostatecznie widzi. Abowie ona jako Królowa i Pani wszystkiego stworzenia widzi w Bogu (co i wszystkim świętym obywatelom niebieskim jest rzecz własna według stany każdego, w którym, żył na świecie mniej albo więcej) doskonałe stany wszystkich tych rzeczy stworzonych; a zwłaszcza rozumianych ludzi i aniołów, nawet i wszystkie ich sprawy zamysły uczyniła potrzeby i myśli najmniejsze gdyż to, jako święty Tomasz Doktor Anielski wwodzi (1. 3. Contra Gentiles c. 59. $)^{28}$ do doskonałości i błogosławieństwa natury rozumniej należy, aby wszystkie rzeczy stworzonych przy-

${ }^{26}$ Divi Petri Damiani episcopi Ostientis Opra omnia... studio et labore D. Constatini Coastani... collecta..., Ludgduni 1623, t. 2, s. 249.

${ }^{27}$ De Vitis Sanctorum ab Aloysio Lipomano Episcopo Veronae... olim conscriptis, nuc priumum a Laurentio Surio Carthusiano emendatis et auctis, tomus primus complectens Sanctos mensium Ianuaris et Febuaris, Venetiis 1581, f. 260-262.

${ }^{28}$ D. Thomae Aquinatis, Opera..., t. 9, cz. 2, f. 298-299. 
rodzenie, moc i przedmiot własne poznała, co się dopiero zastanie przewidzenie istoty Boskiej, które w niebie, Święci mają.

Czego iż Błogosławiona, doskonałej niżeli inszy wszyscy Święci dostąpiła, pokazuje się, aczkolwiek z tego, że Panią jest wszystkiego stworzenia jakim panem żaden inszy Święty nie był, a do rządu dobrego Panu Każdemu należy, wiedzieć sprawy i zamysły poddanych swoich, tedy i z Doktora jednego Teologa Franciszka Suareza (Tom. 2, in 3. P. D Thomae disp. 21 sec. 2. §. 3. Ex his $)^{29}$ gdy tak o tym mówi: Pobożne to i dowodnie trzymam, iż Najświętsza Panna, widzi w przedwiecznym Słowie, wszystkie rzeczy, którekolwiek Bóg sam widzi, i wie, wiadomościa tą, która Dekreta o sprawach natury rozumnej zawiera i aprobuje; oprócz tych jednak samych, które szczególnie do Chrystusa Pana i do jego myśli zewnętrznych należą.

Co gdyż tak jest; jakoż jest prawdziwie, któż się oczu jaśniejszych niżeli Anielskie, jakie jej Ephraem Syrus (Serm. de SS Virginis laudibus ${ }^{30}$ ) przyznawa uchroni? Czy ich ona potrzeba, czyjej nędzę utrapienia, ubóstwa frasunki, nie ujrzy? Czyjego wołania i rzewnego płaczu nie usłyszy? Stąd pochodzi, iż ona mając serce bardzo litościwe; i utrapienie sług swoich, gdy patrzy na nie, długo znieść nie mogąc; i utrapienia sług swoich, gdy patrzy na nie, długo znieść nie mogąc; sama modlitwy i ofiary, jako mąż jeden dokonały (Idiota in Prologo Contemplationis de B.V. ${ }^{31}$ ) mówi; a osobliwe te które do niej czynimy, i jej polecamy zanosi przed Majestat Boga najwyższego; i tam je przekłada za nie wstawiając. A bowiem ona jest orędowniczką naszą i Syna swego; u którego i u Ojca niebieskiego, wyprawuje dekret na prośby, i podpisy na wszystkie nasze, suplikacje nasze; i często do tego przychodzi, że którzy sprawiedliwym sądem od Syna jej skazani, być mogli na wieczne podepnie; Matka ta litościwa, uprasza im, miłosierdziem swoim wyzwolenie. A bowiem ona jest Podskarbiną Pańska, i obwitych łask jego Szafarką.

Lecz nie tylko Podskarbiną i szafarką Pańską jest. Bogurodzica Panna z której miłosierdziem łask, zbawienne potrzebne nasze każdego dnia otrzymujemy; ale Przewodniczką jest; która przez tę drogę doczesnego pielgrzymstwa naszego przeprowadza nas do ojczyzny, i do prostu szczęśliwości wiecznej. Dobrze ją bardzo Doktorowie GWIAZDĄ MORSKĄ zowią: która na burzliwym morzu świata tego, do bezpiecznego portu drogę pokazuje. Której

\footnotetext{
${ }^{29}$ Suarez Franciscus SJ, Commentariorum ac disputationum in tertiam partem Divi Thomae..., Venetiis 1605, t. 2, s. 214.

${ }^{30}$ Sancti Ephraem Syri... Ephraem Opera Omnia in tres tomos digesta, Gerardo Vassio interprete, Coloniae Agrippinae 1603, t. 2, s. 291-300.

${ }^{31}$ Marguerin de La Bigne, Magna Bibliotheca Veterum Patrum, t. 10, s. 27-30.
} 
się słodki Doktor Kościelny Bernard Święty przypatrywać, i do nie (Homil. sup. Missus est) $)^{32}$ udawać się każe. Jeżeli prawi, na cię powstana wiatry rozmaitych pokus; jeżeli napadniesz na skałę ucisków pojrzyj na Gwiazdę a wyzywaj MARYJĘ. Jeżeli cię pogrąża nawałności, $i$ woda pychy, nadętości, nienawiści jakiej, pojżyj na Gwiazdę, a wzywaj MARYJEJI. Jeżeli gniew, łakomstwo, abo cielesne idzie szturmy, na tódkę duszy twojej wywarte będa ja tłukły zatapiały pożyj na MARYJĄ. Bo na nia (to jest na gwiazdę) mówi także Bernard święty (Serm. 20 $0^{33}$ ), patrząc drogi nie ustapisz: memi proszac nie zdesperujesz) o niej myśląc zbłądzić nie będziesz mogła, gdy cię poprowadzi, nie spracujesz się: gdy na cię łaskawie będzie, do prostu bezpiecznego przydziwniejszej. Niechajże tylko mówi o tenże Bernard Święty (de Natiuit Virginis) ${ }^{34}$ te gwiazdę morska MARYJĄ odejma Gwiazdę, mówiq morza tego wielkiego i szerokiego, cóż ci zostanie, tylko mogła obtaczająca, cień śmierci gęste ciemności?

Jest jeszcze MIASTEM UCIECZKI dla grzesznych; WIEŻĄ DAWIDOWĄ; TARCZĄ mocną od nieprzyjaciół dusznych nas broniącą i sposoby obrony statecznej podstawiającą. Ty o Błogosławiona Panno mówię Bernard S (Serm 4. Sup. Salue Regina ${ }^{35}$ ) wieżą jesteś zbudowaną z basztami mocnymi. Bali się nieprzyjaciele twoi abyś znajdź nie Ty oną białogłową była, prze którą zwalczeni, porażeni być i potępieni mieli, dla tegoż była im tak straszną, jako obóz mający porządne wszystkie swe uszykowanie. Nie ma przystępu nieprzyjaciel żaden do ciebie, ponieważ nad murach twoich tarcza hartowne tysiącami wiszą i wszelakie oręże do obrony, mocarzom tej wieży strzegącym potrzebne. Nie masz abowiem się mocy, nie masz cnoty żadnej, któraby nie w Tobie nie znalazła. Cokolwiek mieli świeci, tyś sama odziedziczyła. Zwyciężyłaś wszystkie godności mocy i zasługi Twoją.

Coby to za Tarcze z tej wieży wisiały, wykłada Tomasz Święty (Opusc. S.) ${ }^{36}$ i tak o tym mówi: Gdy w Piśmie Świętym czytamy, że Tysiące tarcz niesie na tobie lekarstwo się przeciwko niebezpieczeństwo dusznym rozumieja.. Ktoby chciał w cnotach się i doskonałości Chrześcijańskie ćwiczyć możesz jej pomóc zadziwiać. I dlatego sama to o somie mówi. We mnie (Eccleastis $24^{37}$ ) wszystka nadzieja żywota (wiecznego) u cnoty.

\footnotetext{
${ }^{32}$ Homilia 2 Super Missus, [w:] Divvi Benardi Opera, Ventis 1583, t. 1, 11v.

${ }^{33}$ Divi Bernardi Opera, Venetiis 1583, t. 1, f. 101v.

${ }^{34}$ Tamże, t. 1, f. 101v.

${ }^{35}$ Tamże, t. 2, f. $292 \mathrm{v}$.

${ }^{36}$ Opus. 8 In Expositione Salutionis Angelicae w D. Thomae Aquin, Opera, t. 17, cz. 1, f. 75-76.

${ }^{37}$ Rozdział 24, wers 25.
} 
Którymi tak łaskawie, i tak miłosiernymi słowy zachęca nas wszystkich grzeszników do tego, abyśmy się jako do Matki Panie Dobrodziejki naszej, zupełnymi afektem i nadzieją wielką utwierdzającym sercem udawali abowiem ona nas, jako dzieci czeladką swoją opatruje i pomoc nam skuteczną dodaje; nie tylko nam do pokus rozmaitych broniąc, póki na tym padole płaczu rzewnego żyjemy, ale na tem czas najwięcej, kiedy po śmierci w godzinę ostateczną, o utratę wieczności szczęśliwości grzesznikowi idzie. Chcesz słuchać przykładu?

Byliśmy białogłowa w Mieście jednym (jako pisze Discpulos Exemp. 73) ${ }^{38}$ zła i grzesznikami swoimi Miasto wszystko gorsząca i zrażająca która przez wszystek czas żywota swojego, dobrego nigdy nie czyniła, oprócz tego: że na cześć Błogosławione Panny pozdrowienie, na każdy dzień z nabożeństwem wielkim odmawiał a w dzień święty Sobotni, Mszą Świętą jedną, na cześć także jej odprawiać kazała. Ta, gdy ciężką chorobą złożona, blisko już bardzo śmierci była, a pomocy żadnej dusznej nie widziała; do Przenajświętszej panny nadziej swoją wszystką obróciwszy, tak do niej mówiła. Pani moja Miłościwa Królowa Nieba i Ziemi, Matko miłosierdzia aczkolwiek wiem że dobrego nigdy nie uczyniłam; przecie jednak mam ufność nieprzebranym miłosierdziu twoim i Tobie przez tej ostatniej godzinie, ducha mojego oddaję. Ledwie to wyrzekła aliści czarci bardzo straszni, jako i lwi okrutni rycerze przypadli, aby dusze jej jako swoją i sobie należącą do piekła porwali. A w tymże momencie stanie przed oczyma ich Przenajświętsza Panna, która się za tę dusze sobie oddaną mocna zastawiając swoją ja być koniecznie twierdziła, a czartem do niej żadnego przystępu nie dając mocną ją od ich drapieży broniła. Zakrzyknął wnet okrutni czarci. Niestety! czemu nam jej bronisz! Nasza jest; i do naszego prawa już dawna należy. Odpowie im na to Matka Miłosierdzia Nie wiecie o tym o sprośni oprawcy, że mię na każdy dzień nabożnie ta dusza pozdrawiała; i Mszą na cześć moją odprawiać kazała? Wiemy odpowiedzą czarci. Ale zbrodni wiele i grzechów bez liczby ciężkich sprośnych naczyniła. Nie tak tym odpowie Przenajświętsza Panna. Idźcie precz a widzicie o tym pewnie: że ta duszą potępiona by nie może żadną miarą, która mi wierni na tym świecie służy i nigdy waszym tem człowiek nie będzie który duszą swoją mojej opiece poleci

38 Sermoned Discipulis de Tempore, et de Sanctis, cum exemplorum Promptuario ac Mircaculis B. Mariae Virginis, Ventiss 1598 (cz. 4), s. 32. - Discipulus (pseud.) - Herolt Joannes OP. Por. . Chevalier, Répertoire des sources historiques... bio-bibliographie, Paris 1905, t. 1, kol. 1202: t. 2, 2134 . 
I tak jest zaprawdę. Żaden mówi Bernard Święty zginąć sługa twój nie może, dla pobożności miłosierdzia twego, o MARYJA Panno ${ }^{39}$. Dobrze o Tobie o Matko Miłosierdzia Anzelm Święty wielki Twój Kochanek powiedział. Jako prawi niepodobna rzecz jest, aby ci od ktoryś Ty oczy Twoje miłosierne odwróciła zbawienni być mogli. Tak i to nigdy nieodmienna, aby ci któryś Ty miłosierne oczy Twoje obróciła i za nim się do Syna Twojego wstawiła, nie mieli być usprawiedliwieni, nawróceni i w chwale wiecznej uwielbieni ${ }^{40}$. Toż właśnie mówi Bonawentura Święty (Specul. B. Virg. c.3) trochę różnymi słowy $^{41}$.

Niechajże teraz, kto tak niewdzięczny, i nie pamiętny wziętych dobrodziejstw wystąpi, któryby to śmiał bezpiecznie wymówić, że sługą i niewolnikiem nie jest MARYJI. Szalonym bym ja takiego nazwał, głupi i rozumu zdrowego w głowie nie mającym, któryby tego nie wiedział który by się nie cieszył, któryby nie pragnął i nie życzył sobie, być Niewolnikiem wiecznym i sługa najniższym Dobrodziejki swojej największej Panny Bogarodzicy MARYJEJ.

Wiedział to dobrze, i te wszystkie tytułu państw MARYJEJ Panny uważał u siebie, Brat Błogosławiony Piotra Damiana, Marynus niejaki, który przez czas nie miał żywota swego. Niewolnikiem się i sługą wiecznym Bożej Panny MARYJEJ i wyznawał, co zrozumiesz, z Części Wtórej niże położone, w której się też początek nabożeństwa tego noszenia Pętek opisuje i jaśnie pokazuje.

Opracował Paweł Rzewuski Uniwersytet Warszawski, Warszawa, Polska genzyp@gmail.com

\footnotetext{
${ }^{39}$ Słowa z modlitwy Memorare przypisywanej św. Bernardowi.

${ }^{40}$ Beati Anzelmi liber de excellentia gloriosissimae Virginis Mariae, [w:] Opera Omnia D Anselmi Cantuariensis archiepiscopi..., Venetiis 1549, cz. 1, s. 169-175.

${ }^{41}$ Sancti Bonaventurae, Operum, t. 6, s. 433.
} 